\title{
Ons kerklied: Prinsipiële en praktiese oorwegings
}

\author{
D J C van Wyk (sr) (Warmbad) ${ }^{1}$ \\ Hervormde Teologiese Kollege \\ Universiteit van Pretoria
}

\begin{abstract}
The church hymn: A consideration of fundamental and practical nature

This study expresses the conviction that the liturgy, hymns and music of the church serve a necessary function and makes an appeal for their regeneration in the church. Such regeneration would, as a consequence of the reflection on and experience of the depth and wealth arising from Biblical songs, foster a deeper love for the hymns and songs of the church. However, at the same time, this study also protests against the tendency, under the pretext of renewal and in unison with the spirtit of the times, to render the ministry, lthurgy as well as the hyms of the church superficial. This study wishes to make an appeal: that we, on the grounds of a better knowledge of the songs of the Bible and the hymns sung throughout the ages, arrive at stronger church songs applicable to present times.
\end{abstract}

\section{INLEIDING}

Hierdie studie gaan voorlopig uit van 'n aanname: dat hernude besinning oor al die aspekte van kerkmusiek, kerklied en kerksang noodsaaklik is. In gemeentes en kerkvergaderings gis en gons dit rondom aandrange en verwagtings van die jeug. Uit sommige kerke en gemeentes word gehoor van kerksangpraktyke wat vir baie ander lidmate van die kerk vreemd, ontstellend en selfs verstommend is. Dit, asook baie ander sake wat nog verderaan ter sprake sal kom, maak herbesinning oor die saak vanselfsprekend.

\footnotetext{
' Dr D J C van Wyk (sr) is dosent van die Hervormde Teologiese Opleiding te Hammanskraal en geakkrediteerde personeellid van die Hervormde Teologiese Kollege, Universiteit van Pretoria.
} 
In hierdie aflewering word by wyse van terreinverkenning slegs stilgestaan by 'n reeks inleidende opmerkings, vraekomplekse en spanningsvelde rondom kerklied en kerksang. In volgende aflewerings sal gehandel word oor voorbeelde van liedere uit die Bybel en om so, na prinsipiele begronding, te probeer kom tot beantwoording van vrae na die waarom en die wat van kerksang en kerklied. Daarna sal oorsigtelik gaan kyk word na voorbeelde van liedere uit die geskiedenis waarna by wyse van 'n slotaflewering, teruggekom sal word op aktuele teologiese en praktiese vraekomplekse. Dit bly vrugbaar om eers na normatiewe begronding en deskriptiewe ontleding riglyne vir die hede te probeer trek.

Maat hier aan die begin word die noodsaak vir vernuwing ook op hierdie terrein beklemtoon. Om 'n nuwe lied vir die Here te sing, is immers 'n opdrag uit die Bybel self (vgl o a Ps 96; 98). Die Bybelse aandrang tot vernuwing is dus konstant, selfs al sou niemand in die kerk daarop aandring nie. As in hierdie bydraes verderaan dus kritiek uitgespreek word teen sekere hedendaagse vernuwingspraktyke rondom kerklied en sang is dit nie verset teen vernuwing as sodanig nie. Dit wil eerder 'n pleidooi wees vir vernuwing wat getuig van Bybelse verankering en geloofsewewig, vernuwing wat verdieping bring, nie vervlakking nie.

\section{DIE KRAG VAN LIED EN MUSIEK}

Maar die Gees van die Here het van Saul gewyk, en 'n bose gees wat deur die Here gestuur is het hom voortdurend ontstel. Die amptenare van Saul het vir hom gesê: U word ontstel deur 'n boosaardige gees wat deur God gestuur is. Die koning moet maar net praat, dan soek ons iemand wat die lier kan speel. As die boosaardige gees u pla, kan die man speel en u sal beter voel....Telkens wanneer die boosaardige gees in Saul was, het Dawid die lier gevat en daarop gespeel. Dan het Saul bedaar, en die boosaardige gees het van hom af padgegee.

(1 Sam 16:14-16; 23)

"This biblical narrative makes a dramatic claim. It suggests that music has a power to penetrate the mind where other forces fail, breaking down barriers directly and imme- 
diately. The mysterious natures of this process and its potency have never ceased to intrigue philosophers and creative artists" (Wilson-Dickson 1992:11)

Wie goed luister, hoor in die psalmboek 'n refrein: God red, die mens sing. In die liedere van die psalmboek tril die verwondering van gelowiges oor die raad, redding, krag en uitkoms wat God gee.

Ek wil sing tot eer van die Here, omdat Hy aan my goed gedoen het

(Psalm 13:6)

Hy het my gehelp

Daarom is ek bly

en wil ek Hom loof met my lied

(Psalm 28:7)

Die psalms is diep deurleefde getuienisse van nou forse, dan weer vallende gelowiges wat sowel in die vreugde as in die angs van die aardse lewe die God van hulle lewe prys of tot God roep, een comblik in die ekstase van die ervaring van tempel en kultus, dan weer in die censaamheid van die woestyn.

Hierdie studie wil vanuit die belewing en die genieting van en ook besinning oor die ongelooflike diepte en rykdom wat uit die Bybelse liedere opklink en ons opwek tot verdere deelname, liefde aanwakker vir die kerklied, oud en jonk; maar dan ook protes probeer verwoord teen die ontstellende vervlakking wat, in ooreenstemming met die gees van die tyd in prediking, erediens, liturgie en daarom ook in die kerksang intree.

'n Ontleding van die Bybelse lied en ook 'n oorsig oor die geskiedenis van die kerklied deur die eeue verraai verrassende vermotns van die liedere. Hulle is vertolkers van geloofs-, kerklike, en teologiese klimaat. Die kerklied weerspiezll die stemming, die lewensgevoel van mense in verskillende stadia van die wereld- en die kerkgeskiedenis. Natuurlik is die kerk- en geloofslied se cerste funksie die verwoording van die gemeente of individuele gelowige se antwoord, gebed, lofprysing of klaagtone. Maar dit ontbloot terselfdertyd ontsaglik baie van die stryd en dwalinge waardeur die kerk moes heen om by die suiwer, ware belydenis van die Drie-enige God en die God se werk tot heil van die 
mens uit te kom. Dit laat klink die kerk en gelowige se triomfe en ekstases, maar ook hulle verplettering en uitwissing tot op die brandstapels.

Mag God ons daarvan bewaar dat ons enigste kerkliednalatenskap aan die kerk op pad na die voleinding toe dít sal wees: oppervlakkige liedere wat wel lekker gesing het, maar die herinnering laat aan mense wat ontredderd en geloofsmoeg was.

Die Afrikaanse kerke ly aan himnologiese armoede. Ons móét nuwe kerkliedinhoud en -idiome skep. Anders het ons niks om na te laat nie en sal die kerk verder net 'n herinnering hê aan ons aaklige geloofsarmoede: Dat ons nie in hierdie Afrikaanse taal en in hierdie wêrelddeel en terwyl ons die tyd gegun was, ons lof- of klaaglied tot God hoorbaar kon kry nie. Maar ons moet hierdie lied bly sing in gemeenskap met die kerk van die ceue. Uit die Bybel self in die cerste plek maar ook uit die eeuelange worsteling van gelowiges om reg oor God se heil en die mens se nood te sing, het ons die norme van wat 'n kerklied is.

Hierdie studie wil 'n appèl verwoord: dat ons op grond van beter kennis van die lied in die Bybel en die kerklied deur die eeue tot 'n sterker kerklied in die hede sal kom.

Ons is miskien geneig om die Nederlanders, miskien ook die Duitsers en andere in 'n mate te beny vir wat ons kan ervaar as egte en ryke himnologiese belewinge en erfenisse. Dit mag 'n mate van troos wees om ook na hulle te luister: "Die Himnologie ist weithin ein Stiefkind im Verband der theologischen Disziplinen; ze leeft cen schacuwagtig bestaan en verkeer in een weinig florissante situatie" (Honders 1988:111).

Die lekker-sing argument wat so holrug gery en dikwels tot enigste norm verhef word, klink mooi en is vir baie mense fassinerend. Maar dit is misleidend en dui juis op 'n ernstige verskraling. Ons kinders moet liewer begrip en anvoeling geleer word vir die veelkleurigheid en krag wat deur die verskeidenheid emosies van die Bybelse liedere gedra en vertolk word. Ons is mense met emosies. In die verskuiwing van die moderne na die postmoderne is dit juis die subjektiewe en die mens met sy soeke na meta-ego ervarings wat groter erkenning vind as in voorafgaande paradigmas van die moderne en die rasionalisme (Dreyer 1999:256). Maar emosies en die subjektiewe is nog iets anders as sentiment. Daarby is vreugde en lekkerkry en lekker sing van vreugde nie die enigste menslike emosie nie. Mense huil ook, ervaar smart, verduur lyding en pyn, kla en kom tot berusting en aanbidding. Mense ervaar censaamheid, vrees, vervolging, tronkstraf, 
berou en smart oor skuld en sonde. Bybelse en kerkliedere help die mens om ook al dié emosies uit te sing en voor God te dra. Mense vir wie alles draai om maklike singbaarheid en lekker sing, ken en verstaan nog min van die werklike krag van die kerk se lied.

\section{SPANNINGSVELDE RONDOM DIE KERKLIED}

\subsection{Spanning en inspanning}

Die twee pole waartussen die kerklied beweeg, God en mens, vorm die kern van die spanningsvelde waaruit die kerklied nie gehaal mag word nie. Die verganklike mens wat vanuit sy gebroke bestaan 'n lied vir die ewige God sing en daarmee vooruitgryp op die volmaakte lied voor die troon van God is tog menslik 'n onmoontlikheid. Om daaraan vas te hou en daarin vol te hou, bring spanning. Die spanning mag nooit eensydig of simplisties opgelos word nie.

Een van die medewerkers aan die Nederlandse Liedboek voor de Kerken, sê oor dié pole waartussen die kerklied gespan word:

- Het moet omdat het toegepaste kunst is, gebruikskunst, lied van de gemeente, aansluiten bij beseffen en termen die in de gemeente leven. Het moet een zekere mate van herkenbaarheid hebben, het mag geen duistere poězie zijn.

- Het moet tegelijk een element van verrassing hebben. Het moet in woord en toon zo zijn gespannen dat het niet na tweemaal zingen al begint te vervelen. De geijkte termen op rijm zijn niet genoeg.

- Het lied moet in de traditie van de kerk weerklinken, maar dat wil niet zeggen dat het in pure nostalgie moet blijven stilstaan bij het verleden. $\mathrm{Er}$ is cen romantiek waarbij waardevolle zaken uit het verleden verabsoluteerd worden alsof ze zaligmakend waren, bijv het stoere tempo der vaderen, of de psalmen van Datheen of van 1773.

- Het moet anderzijds niet met elke mode, elke wind van leer mee gaan, niet meehijgen in het opgehitste ritme van het moment. Wat vandaag populair is en menigten trekt, is morgen vervaald en voorbij.

- Het lied moet een echo vinden in het geloofsleven. Dat wil dus ook zeggen in ons gevoel, maar het moet daarom nog niet sentimenteel 
worden. Daar ligt het grootste probleem. Juist in het zingen zijn wij zo gemakkelijk los van onze rationele remmingen en dat moet natuurlik ook. Maar wanneer wij ons laten meeslepen op de stroom van onze gevoelens, wordt dat gauw een vormeloze, ordeloze zwijmelarij. Het is het oeroude probleem van de eredienst waar Paulus in 1 Cor. 14 al zo indrukwekkend over schrijft: "Ik zing met geestdrift, maar ook met verstand". Waar Augustinus mee worstelt: "Zo schommel ik heen en weer tussen de overweging van het gevaar van het zingen als enkel genot en de heilzaamheid die er in kan zijn". Het lied mag niet, zo bedoelen beiden, ontaarden in sentiment en zeker niet in onbestemde extase.

- Het mag ook geen berijmde dogmatiek worden. Het liedboek kan niet met een dogmatische meetlat worden rechtgetrokken. Hoe bewonderenswaardig, hoe noodzakelijk het ook is om de waarheid te benaderen met het dogma, in het zingen doet de mens iets anders, verwijdt hij de grenzen, zet hij de woorden, alleen helemaal aanwezig, in cen ruimte groter dan die van alledag. Daar is protest, daar is mystiek, daar is wanhoop en daar is troost.

(Schulte Nordholt 1981:39)

Dié spanning loop deur tot op die vlak van die himnografie, die maak van 'n kerklied; daar waar berymer of digter en komponis met hulle skeppende werk besig is; en dit dan kom voorlê aan die teoloog, die dogmatikus, die literêre kritikus, die taalkundige, die kerkmusikus; en moet ervaar dat wat miskien net hy self as kunswerk becordeel, of wat dalk deur almal as geslaagde kunswerk beoordeel word, deur die sif en die meule van 'n kerklike kommissie moet heen. Oor die spanning en frustrasies wat dié proses na alle kante meebring, sal 'n paar boeke geskryf kan word.

Die Nederlandse kerke van die vyftiger en sestigerjare was bevoorreg dat van die toonaangewende Nederlandse digters geīnteresseerd en betrokke geraak het by die skepping van 'n nuwe liedboek. Die Afrikaanse kerke was minder bevoorreg. Aan die samestelling van die Gesangbundel van 1978 het geen enkele Afrikaanse digter van faam deelgeneem nie. Is dit omdat die Afrikaanse digters buitekerklikes geword het? Of het 
die Afrikaanse kerke ons digters langs die pad verloor? Wat sou in albei gevalle die redes daarvoor mag wees? Gelukkig het in die Liedboek van 2001 in hierdie opsig verandering gekom.

Wie moet finaal beshuit oor die geslaagdheid al dan nie van 'n kerklied? Moet dit langs die weg van 'n "demokratiese" proses? Maar is dit nie, behalwe dat dit onkerkregtelik is, ook 'n onverantwoordelike tegemoetkoming aan niks meer as die populêre smaak nie? Het die kerk in die persoon van 'n kerkliedkommissie nie ook 'n opvoedingstaak in hierdie opsig nie? Wie maak final uit wat waarheid en wat skoonheid is? Gladgestrykte definisies is eenvoudig. Maar werklike waarheid en skoonheid is meer as dit.

Maar die kerklied dra nie net spanning saam nie. Dit vra ook inspanning. Oor die hele wye front van kerk en geloof kry die spontane in ons tyd 'n onverantwoordelike en ongehoorde vrye baan. Wat spontaan en maklik is, ook in die kerksang, is aanvaarbaar. Maar dit is ook goedkoop! Is ons bereid om ten opsigte van prediking, liturgiese vorm en offergawe so aan die spontane vrye teuels te gee? Indien nie, waarom dan ten opsigte van die kerklied?

Indien wat die gemeente in die prediking moet hoor, net die beste mag wees waartoe die prediker in staat is, moet dit wat God aanhoor as lofprysing op God se goedheid, ook net die beste wees waaroor die kerk beskik.

Wij geloofden dat we het beste wat maar mogelijk was moesten zien to bereiken in het liedboek, dat wij in cen boek dat bedoeld is om God te loven niet achteloos te werk konden gaan. Dat dat beste niet zomaar voor het grijpen lag, maar verworven moet worden in jare van toewijding en tucht, cerst van de dichters en musici en vervolgens ook van de gemeente. De dingen die waarachtig zijn in het leven, zijn nooit vanzelfsprekend, nooit makkelijk, nooit uit te tellen, nooit te koop.

(Schulte Nordholt 1981:38)

Dit blyk telkens dat in lied wat vir jare in 'n gemeente as onsingbaar. geag is, skielik pragtig singbaar en selfs geliefd raak net sodra 'n predikant, orrelis of sangleier bereid 
raak om 'n gemeente met 'n bietjie oefening in die sing daarvan te lei en te help. Maar hier, net soos op so baie ander terreine in die kerk, is een van die oorsake van ons ellende ons luiheid om ons in te span in die diens van God. Veral wys die vinger na die ouerhuis waar kinders nie liefde leer en ervaring smaak in die sing van die kerk se lied en waardering vir die kerk se eie styl en idioom nie.

\subsection{Bybel, gemeente en erediens.}

Met kerklied word bedoel die lied wat die Christelike gemeente in die erediens sing. Dit word onderskei van kerkmusiek, die musiek wat byvoorbeeld op die orrel of op ander instrumente deur kunstenaars uitgevoer word of wat deur kore gesing word. Die erediens is die plek en gebeure waar God en mens mekaar ontmoet. Die inhoud van hierdie ontmoeting is die Woord van God en die antwoord van die mens.

Om van kerklied te praat, moet daar dus 'n gemeente wees, daar moet erediens wees en daar moet 'n lied wees; 'n lied waarin mense hulle geloof vertolk en waarin hulle sing van die werk van God soos hulle dit uit die Bybel leer ken het. So nou is die kerklied aan die Bybel verbonde dat dit eintlik nie verskil maak of ons praat van die lied in die Bybel of die Bybel in die lied nie.

Sonder om nou reeds in te gaan op wat Paulus waarskynlik bedoel het met psalms, lofgesange en ander geestelike liedere (Kol 3:16, Ef 5:19), moet dus gestel word dat 'n kerklied iets anders is as.'n kunslied of 'n volkslied. Ook op die saak van die kerklied as volkslied, sal in 'n latere paragraaf krities teruggekom word, maar op hierdie stadium kan voorlopig gestel word dat die opvatting van baie dat die kerklied dikwels uit die volkslied ontwikkel, nie houdbaar is nie. In die kunslied of volkslied is dit of nie die gemeente wat dit sing nie of die plek waar dit gesing word, is nie die erediens nie of dit besing iets anders as God se werk soos die Bybel dit leer.

In die Bybel is God en mens aan die woord. In die Bybel le Israel getuienis daarvan af dat Israel die Woord van God gehoor het en wat Israel as antwoord daarop gegee het. In hierdie getuienis van Israel le die nadruk op die Woord van God. God voer egter geen monoloog nie. God vra om 'n antwoord. God se Woord in die Bybel vorm die raam en skep die ruimte vir die dialoog. met Israel. Hierdie wisselwerking tussen Woord en antwoord het neerslag gevind in verhale, liedere, spreuke, gesprekke en 
gebede. Daarin gee God se Woord die toon aan waarop mense antwoord. God se Woord gee die taal aan waarin mense hulle antwoord gee. Gelowiges se antwoord lê 'n verklaring af van hulle geloof, doen verslag van God se goeie dade aan hulle (Van Uchelen 1983:24).

Wie hierdie binding van die kerklied aan God se werk, aan die Bybel, aan die erediens van die gemeente van Jesus Christus loslaat, het reeds die wesenlike van die saak prysgegee. So 'n mens mag 'n lied sing wat pragtig is en bekoor, wat op enige plek gesing kan word of wat oor alles van die mens sing. 'n Kerklied is dit nie. Soos wat daar in die kerklied deur die gemeente in die erediens gesing word, word daar nêrens elders in die wêreld gesing nie.

\subsection{Tussen tradisie en vernuwing}

Wat God gedoen het, en wat God gaan doen. In die spanning tussen dié twee leef die gemeente. Daar sing die kerk liedere; beoefen die kerk doksologie. Waarop die Bybel ons aandag toespits, is sowel perfektum as futurum, verlede en toekoms. Die Here het gekom. Die Here kom.

Dié wesenlike spanning kenmerk die ganse geloof van die kerk, daarọm ook van die kerklied en sal en behoort dus ook nooit opgelos te word nie. Daaruit is miskien die eienaardige verskynsel wat soms lyk na 'n vorm van skisofrenie by gelowiges ten opsigte van die kerklied te verklaar. Lidmate van die kerk verlang sterk na muwe liedere wat die moderne lewensgevoel vertolk. Terselfdertyd verset dieselfde lidmate hulle teen 'n nuwe liederebundel en wil graag die ou bekende en maklike liedere bly sing.

In werklikheid dui dit op 'n wesenlike spanning wat eie is aan die aard van die geloof en die kerklied. Gelowiges hét behoefte aan nuwe liedere om hulle geloof in God hier en nou te vertolk. Maar van dieselfde God het hulle groot skatte in die verlede ontvang wat hulle wil bewaar.

Sommige kan net die nuwe, die moderne waardeer. Hulle het niks aan die ou goud nie, maar soek nuwe goud. Met ander is dit weer so dat hoe ouer 'n kerklied is, hoe beter is die kans dat hulle die kwaliteit daarvan sal insien. Vir 'n baie lang tyd het almal saamgestem dat die Nederlandse psalmberyming van 1773 vol rasionalistiese invloede van die agtiende eeu se verligting was. Maar toe daar in 1967 'n nuwe psalmberyming in 
Nederland verskyn, het konserwatiewe teoloe skielik baie gunstiger oor die 1773 beryming begin oordeel (Sturm 1977:10).

Tot twintig jaar gelede het min teoloæ en kerkmusici 'n goeie woord vir die negentiende eeu se kerklied gehad. Dié liedere was te veel gerig op die individuele emosie en is strydig met die objektiewe karakter wat die kerklied behoort te handhaaf. Vandag het dié oordeel in baie opsigte al weer verander en word aanvaar dat ook die negentiende eeu se kerklied wesenlike aspekte van die geloof vertolk het. Warmte, innigheid en emosie kan in 'n verkeerde rigting ontwikkel, maar is nie noodwendig verkeerd nie.

Ons staan dan dadelik ook hier voor die moeilike vraag van die verhouding van die kerklied tot die kultuur van 'n bepaalde tyd. Dit is een van die ernstigste spanningsvelde waarin die kerklied voortdurend leef. Elke goeie liederebundel weerspiexl iets van die eie tyd. Die kerklied mag nie 'n totale vreemdeling wees in die tyd waarin dit gesing word nie. Soms word beweer dat ons huidige Afrikaanse kerklied te ver verwyder, te vreemd geword het aan ons eie tyd en kultuur. Die vraag kan natuurlik ook van die ander kant af gestel word. Is dit werklik die kerklied wat vervreem het van ons tyd en kultuur, of is dit dalk moderne gelowiges wat vervreem het van hulle geestelike erfgoed?

Ons gee dus toe dat die kerklied nie vreemd staan teenoor die kultuur van die tyd nie, maar die goeie kerklied word ook nooit totaal aan die tydgees uitgelewer nie. Waar dit wel gebeur, is daar niks blywends in die kerklied nie. Vandag is dié kerklied 'n treffer, môre weer 'n ander. Die goeie kerklied wat werklik karakter het, bly relevant en verander nie so maklik nie. Dit bewar 'n sekere afstand en reserwe ten opsigte van die eietydse kultuur en strominge. Die geskiedenis toon telkens aan of die kerklied van 'n bepaalde tyd blywende waarde gehad het en of tydgebondenheid sy enigste kwaliteit was.

Die geskiedenis van die kerk het 'n enorme hoeveelheid liedere gelewer wat baie gou vergeet is en verdwyn het. Maar daarnaas het dit 'n ryk skat van liedere gelewer wat die eeue oorleef het. Dit is onkunde oor dié rykdomme van die verlede wat veroorsaak dat ampsdraers en lidmate die kerklied wat 'n brug met die verlede vorm, as onbruikbaar en verslete afskryf. Dan word aansluiting by die moderne lewensgevoel die hoogste norm vir 'n aanvaarbare kerklied. 


\subsection{Estetiese gehalte en singbaarheid}

Daar is ook spanning rondom die vraag na die verhouding tussen die estetiese gehalte van die kerklied en die bevattingsvermoe van die gemeente. Die blote opname van ' $n$ lied in 'n bundel maak nog nie van so 'n. lied 'n goeie kerklied nie. Daar moet iets bykom: Die gemeente. Daar sou te alle tye 'n kerklied van baie hoe gehalte gemaak kon word solank daar net nie 'n gemeente is wat dit moet sing nie. Daar móét rekening gehou word met wat die gemeente kan sing.

Maar singbaarheid en veral die lekker singbaarheid is nie die enigste norm vir 'n kerklied nie. Die goeie kerklied moet ook esteties van gehalte wees. In Calvyn se woorde: Dit moet gewig en majesteit hâ. Dit moet gepas wees vir die gewyde atmosfeer van die erediens. Dit moet 'n waardige draer en vertolker van God se lof en die geloof van die gemeente wees. Van die resente Engelse kerkliedere skryf Wim Kloppenburg (1983:120):

Ook daar is een grote produktie van nieuwe liederen; men spreekt zelfs van een "Explosion of British hymnody". Maar die melodiezn zijn of traditioneel 19de-eeuws, of nadrukkelijk "popular". En de teksten? "Life is great". "God is love". "We should love each other". Er is geen speld tussen te krijgen. Maar als de bijbelse boodschap zo simpel is, waarom is de Bijbel dan zo 'n dik boek? Of wil ik als calvinistische Nederlander toch weer te veel theologie in de liederen stoppen. Moeten we niet onbekommerd kunnen zingen?

Wanneer die onbekommerde, lekker sing tot enigste norm vir die kerklied verhef word, word die klem te eensydig op die sing met die hart gelê. Daar word vergeet dat Paulus ook oproep om die lof van God met die verstand te sing (1 Kor 14:15). Daar is liedere, soos Psalm 38 of 51 of 119 wat nie juigend gesing kan word nie, maar slegs klaend of skuldbelydend of peinsend.

\subsection{Plek en invloed van die kerklied}

Hoe hoog ons ook al die krag en betekenis van musiek en die kerklied aanslaan, moet die belangrikheid van kerksang nie cordryf word nie. Die kerklied, in samehang van woord en melodie, mag nooit die Woord van God uit die sentrum van die erediens verdryf nie. 
Wanneer lidmate nie meer eredienste wil bywoon nie of die kerk verlaat omdat die sang swak is, word die betekenis van sang totaal corskat en openbaar dit 'n ernstige misverstand oor waarom dit wesenlik in die erediens gaan. Musiek het in die erediens 'n dienende funksie. Dit heers of oorheers nie. Dit dien en dra die teks. Ondanks sy passie vir die kerklied, het Van der Leeuw (1948:282) gesê die musiekaspek van die kerklied kan 'n onding word. Musiek kan nie praat nie, preek nog minder. Vir die prediking is musiek volstrek sonder betekenis. Veral meesleurende musiek vervaag die Woord.

E C Kloppers het in die jongste tyd belangrike bydraes, waarvan sommiges skerp krities, tot die gesprek oor die funksie en plek van die kerklied gelewer. Sy staan byvoorbeeld krities ten opsigte van die sentrale plek wat die "Woord - as God se Woord draer van die openbaring, as mense-woord die primêre, selfs die uitsluitlike medium van verkondiging" in die dialektiese teologie gekry het (Kloppers 1999:297). Dit het volgens haar tot sodanige verabsolutering van die gesproke woord gelei dat enige handeling náás die gesproke woord in 'n tweederangse posisie geplaas is en dikwels selfs teologies uitgeweer is. Dié opvatting wat tot ongeveer twintig jaar gelede algemeen in Reformatoriese kerke aanvaar is, het daartoe gelei dat die teologiese besinning oor die kerklied in dié kerke tot op daardie stadium grootliks vermy is. Toenemend het die siening egter deurgedring dat nie net die woord-Woord, met ander woorde die gesproke woord die verkondiging dra nie, maar dat simbole, kuns, poessie, metafoor en musiek 'n onlosmaaklike element van alle geloofsverkondiging, geloofsbelewing en geloofsuitlewing vorm (Kloppers 1999:297).

Kloppers se siening beteken dat die kerklied nou nie meer net draer van die gemeente se antwobrd op die woord is nie, maar dat dit self ook verkondiging kan word. Dit impliseer inderdaad ook 'n verskuiwing weg van die standpunt wat hierbo gestel is or die dienskneggestalte van die musiek, die siening van Van der Leeuw en die gangbare opvattings in die dialekties-reformatoriese teologie. Dié verskuiwing is nie noodwendig verkeerd nie, maar behoort baie dieper beredeneer te word.

Intussen word hier volstaan met die stelling dat die belangrikheid van kerksang nie oordryf moet word nie. Maar dit moet ook nie geringgeskat word nie. Afgesien daarvan dat dit 'n wesenlike element in die liturgie uitmaak, het musiek, soos reeds aangetoon, 'n sterk greep op die gees van die mens. In die lewe van 'n groot persentasie 
lidmate van die kerk speel musiek 'n wesenlike rol. 'n Belangrike deel van hulle daaglikse lewe word met musiek gevul. Dink vir 'n oomblik na oor die enorme volume musiek wat daagliks in die wêreld gemaak word, op skool, in konsertsale, in huise, op televisie, oor die radio, in die kerk, in die gedagte van mense wat fluit of neurie by die werk. Daarom moet die kerk aanvaar dat lidmate nie afsydig sal staan van die gehalte en aard van die musiek en sang wat hulle in die erediens beleef nie. Hulle sal geneig bly om dit te vergelyk met wat hulle elders beleef.

Daarom bly dit 'n relevante vraag: Is die afstand tussen die moderne sekulêre musiek en die kerk se sang en musiek nie te groot nie? Hoe moet die moderne jeug vanuit hulle musiekwêreld tuis voel in die kerk?

Dit is vrae wat gestel word. 'n Ander vraag is natururlik of die kerk en ouers vir hulle kinders liefde vir en kennis van die erediens, liturgie en kerklied bybring? Daar is tog talle lidmate wat tuis is in albei wêrelde. Is dit nie juis dié gebrek aan kennis en liefde wat mense ontuis laat word in die erediens nie? En dan veroorsaak dat hulle die musiek wat hulle ken en wat vir hulle geliefd is, in die erediens wil indra nie?

\subsection{Is herbegronding dan werklik nodig?}

Invloedryke teoloe beweer tans dat die Reformatoriese paradigma in die geskiedenis van kerk en teologie agter die rug is (vgl o a Bosch 1991:4).

Die sestiende-eeuse kerkhervorming hét sterk invloed op die kerksang in die Protestantse wêreld gehad. Soos die Reformatoriese teologie dra ook die Reformatoriese kerklied 'n sterk objektiewe karakter. God, - God se liefde, genade en heilsdade - staan in die middelpunt; nie mense, hulle geloof, vroomheid of ervarings nie. Indien dit waar sou wees dat daar aangekom is by die einde van diè Reformatoriese paradigma in kerk en teologie, sou dit ernstige gevolge vir die Reformatoriese kerke se kerklied inhou. Want in die meeste kerke uit dié tradisie word die Geneefse kerklied en kerkliedstyl steeds gehandhaaf en hoog aangeslaan.

Indien Bosch (1991:349-519) verder reg is dat die teologie nou by 'n ekumeniese paradigma uitgekom het, is eise vir 'n ekumeniese kerklied, of vir 'n kerklied met inhoud en styl van die bevrydingsteologie, relevant (Oosterhuis 1983:55). 
Intussen word kerk en wêreld oorspoel deur 'n vloedgolf charismatiese godsdienstige uitinge. Daarvoor is die moderne mens in sy ontreddering en nood sensitief en vatbaar. Vandaar die sterk aandrang vir charismatiese kerksang.

Is prinsipiēle begronding van die kerklied dan werklik nodig? Is die probleem rondom kerklied en kerksang dat daar lidmate is wat meen daar moet nie in die erediens gesing word nie? Moet hulle met Skrifbewyse oortuig word? Met ander woorde, leef daar nog iets by ons van die opvatting van Zwingli wat in die kerksang van sy tyd geen spore van dankbaarheid kon vind nie, maar net van menslike roem en geldsug? Hoewel Zwingli musikaal en esteties 'n hoogs ontwikkelde mens was, was hy tot verset teen sang en musiek in die erediens gebring deur die prag en praal wat hy ook in dié opsig in die kerk van sy tyd beleef het (Den Besten 1977:73).

Oppervlakkig beskou, sou dit kon voorkom of die kerk vrae oor die waarom van die kerklied agter die rug het en dat dit vandag meer gaan oor vrae wat op die praktiese vlak lê: Hoe moet daar in die erediens gesing word? Wat moet daar gesing word? Moet van die jeug verwag word om by byeenkomste van geestelike aard dieselfde liedere te sing as wat in die kerk se amptelike liedboek staan of moet toegegee word aan die eis vir verskillende, aanvullende bundels? Bied die Bybel enige antwoorde op hierdie praktiese vrae waarvoor die kerk staan? Of is dit net 'n kwessie van kerklike beleid? Is die teologiese inhoude wat dan agter dié beleid staan, relevant en verantwoordbaar vir vandag?

Moet daar net psalms gesing word of ook gesange? Hou die geskiedenis van dwalinge rondom gesange en gesangbundels nie vir die kerk ernstige waarskuwing in nie? Moet daar dan toegegee word aan die eis vir meer en meer en nog meer gesange?

By dieper nadenke lyk dit tog na 'n verskraling en oorvereenvoudiging om die problematiek net na die praktiese vlak te verskuif en te meen dat vrae na die waarom, die prinsipięle begronding van die kerklied, nie meer relevant is nie.

Die vraag na die waarom mag uitgemaak wees in die gemoed van predikante en teoloè, dit mag teologies wel georden in kanne en kruike staan, maar is dit ook so in die hart en gemoed van die gemeente? Is die kerk geneig tot die lof van God? Waarom is so baie lidmate so min lus daarvoor? Waarom is daar so 'n himnologiese bloedarmoede in die kerk? 
Die rede vir die lusteloosheid in baie gemeentes se sang is waarskynlik totaal iets anders as by Zwingli. Maar dit bly 'n wesenlike probleem. Daarom lyk voortgaande besinning oor die prinsipiěle begronding van die kerklied sinvol en selfs noodsaaklik.

As die vraag na die waarom in die gemoed van die gemeente opgehelder is, sal vrae oor die wie en die wat en die hoe nie meer die lof van God laat verstom nie. Baie staan of sit blykbaar in die erediens met meer vrae as vreugde. As die kerk opnuut en vars geneig en gemotiveer raak vir die erediens en die lof van God, sal gebreke in die liedboek nie meer tot kerkverlating lei nie. Daarom staan ons by die aanname waarvan in die begin uitgegaan is, naamlik dat hernude besinning oor die kerklied dringend nodig is. Om dit te doen, is ' $n$ Bybels-teologiese begronding van die kerklied nodig. Daarnaas is dit egter ook noodsaaklik om 'n behoorlike corsig te kry oor die gang en geskiedenis van die kerklied deur die eeue. 'n Skare van digters, apostels, profete, komponiste en sangers het gepraat en gesing van die heil van God vir mense. Dit is argeloosheid en onkunde ten opsigte van dié liedere wat gehelp het om die kerk deur eeue se stryd en lyding te dra en te louter, wat maak dat gelowiges so maklik ingenome is met enige oppervlakkige liedjie wat in die erediens ingevoer word.

Nog 'n fassinerende maar spanningsvolle aspek van 'n besinning oor die kerklied is die invloed wat die wêreld- kerk- en musiekgeskiedenis, asook teologiese ontwikkelinge daarop het. Van kerkliedbundels word nie sonder rede gepraat as kompendiums van teologiese inhoude nie. Ook daarom pas by herbesinning ook 'n oorsig oor die kerklied deur die eeue.

Kerk en wêreld het tans nie net aan die einde van nog 'n eeu aangekom nie. Die einde van die twintigste eeu word ook gekenmerk deur epogmakende grondverskuiwings in sowel die kerklike as die geestelike lewe van die mensheid. Die ingrypende veranderings wat in hierdie postmoderne tyd afspeel, sal ook die lewensgevoel van gelowiges diepgaande beinvloed. Die kerk moet gereed wees om talle vrae rondom die teologie, erediens en liturgie te hanteer en te beantwoord.

\section{SAMEVATTENDE EKSKURS}

Talle fasette van ons onderwerp moet tans oorstaan vir latere behandeling. Hier word volstaan met 'n kort ekskursie oor 'n eerste paar grepe wat gemaak is en vraagstukke wat aangestip of selfs net geimpliseer is. 


\subsection{Invloed van wêreld-en kerkgeskiedenis}

Daar is terloops reeds gewys op die invloed wat die wêreld- en kerkgeskiedenis asook teologiese ontwikkelings op die kerklied het. Die kerklied dra meermale die tekens en littekens van wat in ' $n$ bepaalde tyd of in die tyd voorafgaande aan die verskyning van 'n kerkliedbundel in die wêreld- en kerkgeskiedenis afgespeel het. Dié invloed blyk telkens uit 'n oorsig oor die geskiedenis van die kerklied. Wat is die situasie vandag? Wat is die faktore wat vanuit die wêreld en die teologie op die samestelling van 'n nuwe kerksangbundel uit die Afrikaanse kerke inwerk?

Het is geen overschatting van een tijdgenoot vast te stellen dat de Tweede Wêreldoorlog de stoot heeft gegeven tot de aller omvangrijkste verandering in de maatschapelijke orde van onze aarde uit de gehele geschiedenis. Kwantitatief gezien zij de veranderingen als gevolg van de liquidatie van vroeger bezweken grote politieke structuren, van de Romeinse rijken tot een Napoleontisch imperium of de Oostenrijks-Hongaarse dubbel monargie kinderspel vergeleken bij de reusachtige transformasies die na de Tweede Wêreldoorlog noodzakelijk, althans mogelijk, worden.

(Hiltermann 1970:14)

Van die medewerkers aan die Nederlandse bundel Liedboek voor de Kerken (Den Besten 1981:19) gee toe dat in dié bundel cen hang naar objectiviteit te bespeur is. Dit was 'n gevolg van die twyfel wat die eerste tien tot vyftien jaar na die oorlog gekenmerk het; twyfel aan die goedheid van die mens, die sin van die lewe, eie vroomheid. Wie orent wou bly, moes dit nie soek in eie geloof nie, maar in die objektiewe, in die Woord.

Intussen het die kontoere van 'n postmoderne wêreld en tydgees al helderder uit die verf begin kom. Saam met die radikale politieke omwentelling in Suid-Afrika het dit vir die kerk hier ongekende nuwe situasies en uitdagings geskep asook ou vasstaande oortuigings begin toets en ondermyn; so byvoorbeeld ten opsigte van Skifbeskouing, die waarheidsvraag, die studie en hantering van die Bybel, die houding ten opsigte van die ander godsdienste, die houding teenoor die kerk se belydenis, die verhouding teologiefilosofie. Die gees wat al duideliker in die paradigmaskuif van die moderne na die 
postmoderne onderskeibaar begin raak het, is dié van oopheid, akkommodering, die bereidheid tot ' $n$ kritiese benadering van wat vasstaande aanvaar word.

Intussen het die ekumeniese teologie van die afgelope eeu 'n deurwerking ook daarin dat kerke en kerkfamilies in Suid-Afrika, Nederland en elders in daadwerklike eenwordingsprosesse gewikkel is. Soos reeds aangectui, dring die ekumeniese teologie die vraag na 'n meer ekumenies-gerigte en bruikbare lied, wat teks en melodie betref, na vore. Daarby kom die opbruisende vloedgolf van sogenaamde charismatiese kerksang, waarby ons straks vir 'n wyle stilstaan.

Die groot probleem met die postmoderne is nie die groter oopheid ten opsigte van bevraagtekening en selfs omvergooi van kerklike gebruike en teologiese inhoude wat ook daarin na vore tree nie. Die probleem is eerder dat die gees van akkommodering en 'n kritiese teologie nie waar en konsekwent is nie. Dit staan akkommoderend na buite, teenoor vreemde leringe van 'n ateistiese tydgees en filosofie, maar is onverdraagsaam na binne, teenoor die eie en beproefde. Dit is skerp krities na binne, teen die eie, maar is veelal kritieklose meelopers met kerkvyandige ideologiez en heidendom. Selfs pogings tot 'n Bybels-gefundeerde kritiek op heidense filosofie en tydgees bly nog uit in die teologie.

Die indruk bestaan dat huidige tendense rondom die kerksang wêreldwyd, maar ook binne die Afrikaanse kerke, enorme teologiese grondverskuiwings wat in die teologie aan die gang is, sal blootlê.

\subsection{Charismatiese kerksang}

Wat is charismatiese kerksang? Dit wil voorkom asof daar rondom die begrip charismaties baie verwarring heers. Breytenbach (1997:1) skryf dat die charismatiese beweging nie 'n homogene verskynsel is nie. Wat waarskynlik gemeenskaplik van al die groepe gesê kan word, is die volgende:

- Daar word aanspraak gemaak op 'n besondere ontmoeting met en vervul wees met die Heilige Gees;

- Hierdie vervul-wees met die Heilige Gees word onderbou deur vertellings oor persoonlike ervaring en die belewing van besondere gawes soos genesing, die spreek in tale en dies meer; 
- Daar word aangevoer dat die eie godsdienstige groep 'n outentieke voortsetting of herlewing van die Nuwe-Testamentiese geloofsgemeenskap is.

Hierdie aansprake kom tot uitdrukking in die byeenkomste

- war 'n onkonvensionele styl;

- massa-emosie, opgewek deur emosionele prediking, ritmiese musiek, sang en liggaamsbeweging;

- en 'n sterk gevoel van gemeensaamheid die toon aangee.

Breytenbach (1997:2) skryf verder dat die gangbare opvatting in die Nederduitsch Hervormde Kerk is dat charismaties veral betrekking het op 'n erediensstyl wat onkonvensioneel is omdat bepaalde liedere wat nie in die Kerkboek voorkom nie, gesing word, en omdat daar op on-Hervormde wyse (dit wil sê met 'n piêtistiese of metodistiese aanslag) opgetree en gepreek word. Dit is volgens hom opvallend dat nie teologiese inhoud as sodanig nie, maar 'n bepaalde styl iemand in die Hervormde kring die etiket van charismaties op die hals haal.

Die hele onderskeiding tussen charismatiese en nie-charismatiese kerke en tussen charismatiese en konvensionele kerksang lyk in elk geval vir my onbybels, verwarrend en misleidend. Die vervul-wees met die Heilige Gees en die gawes wat die Heilige Gees gee, is in die Nuwe Testament 'n gegewe werklikheid wat deur niemand ontken word nie (vgl o a Hand 2; 1 Kor 12 en 14; Rom 12). Op dié verskeidenheid genadegawes wat die Heilige Gees gee, moet die gelowiges hulle toelê, veral op dié om God se boodskap te verkondig (1 Kor 14:1). Daar is nie gelowiges of kerke wat hulle daarvan kan losmaak of distansieer nie. Waar dít gebeur, gaan 'n kerk dood, dit word 'n geraamte sonder siel, sonder lewe. Daarom behoort daar geen kerk te wees wat ontken dat dié kerk in hierdie Bybelse sin charismaties is nie. Niemand kan ook sê dat Jesus die Here is nie, behalwe deur die Heilige Gees (1 Kor 12:3).

Maar aan die ander kant kan geen kerk charismaties wees in dié sin en met dié implikasie dat daar nie meer vasgehou word aan die hart van die Nuwe-Testamentiese getuienis dat Jesus werklik die Christus, die Seun van die lewende God, die Verlosser van die wêreld is nie. Waar dit gebeur, verval die kerk tot 'n stuk swewende spiritualisme 
waaraan massas mense mag deelhê. Liggaam van Christus, gebou van God, kudde van Jesus Christus is dit egter nie meer nie.

Die liedere van die kerk behoort in teks en melodie van albei hierdie Bybelinhoude, naamlik dat Jesus die Christus is en die vervuldheid deur die Heilige Gees deurdronge te wees en dit te dra. Die vrugtelose onderskeid tussen charismaties en niecharismaties of konvensioneel behoort gelaat te word. Waar gelowiges behoefte het om hulle sterker toe te lê op die gawes van die Heilige Gees, behoort dit nie deur die kerk negatief bejeen te word nie. Gelowiges wat gelukkig is daarmee dat in verkondiging en sang oorheersende klem gelê word op Jesus die Christrus se werk tot behoud van sondaars, hoort nie daarom vanuit charismatiese hoek as minder of swakker in die geloof beskimp te word nie. Ons is as mense nie almal dieselfde nie. Daarom kan daar in die kerk duldbare verskeidenheid wees.

Waar charismaties bloot 'n skans is om eiewilligheid, willekeur en 'n verset teen die goeie kerklike orde te verbloem, is dit onaanvaarbaar en verwerplik; ook daar waar dit aanleiding gee tot en 'n uiting is van sektariese hoogmoed en meerderwaardigheid teenoor medegelowiges of sommer net 'n drang om 'n stuk wêreld in die kerk in te dra.

\subsection{Die saak oor die objektiewe}

Die woord objektief is reeds enkele kere in die voorafgaande paragrawe gebruik en sal ook nog verder voorkom om wesenlike dinge oor die kerklied te sê en om belangrike onderskeidinge aan te dui.

As gevolg van die huidige afkeer en wegskram van die term objektief en die skema subjektief - objektief soos dit in die moderne- en verligtingsdenke sterk gefigureer het, is dit nodig om 'n verantwoording te bied oor die gebruik van die terme in hierdie studie. Dié afkeer leef ook wyd in die Hervormde teologie; so ook die afkerigheid van 'n opvatting wat waarheid sien as objektief vasstelbaar, bewysbaar of wat bloot in proposisies uitdrukking vind.

Bosch (1991:262) toon aan dat die moderne of Verligtingsera vanaf die sewentiende eeu te voorskyn tree, nadat eerste tekens van die disintegrering van die middeleeuse wêreldbeeld reeds sedert die veertiende eeu begin sigbaar word. Bosch noem sewe onderskeibare kenmerke van die moderne Verligtingsparadigma. Een daarvan is die subjek - objek skema. "This meant that it separated humans from their environment and 
enabled them to examine the animal and mineral world from the vantage point of scientific objectivity" (Bosch 1991:264). Die skepping word objek van die mens se analise. Die klem val nie meer op die geheel nie, maar op die dele. Dit lei tot matelose selfvertroue om die fisiese wêreld te manipuleer en te eksploiteer.

In die postmoderne denke het hierdie subjek-objekskema totaal verkrummel. Daar word holisties gedink en nie analities nie. Bymekaar-wees word beklemtoon bo afstand. Die dualisme van liggaam en verstand - subjek en objek is deurbreek (Bosch 1991:355). Hierdie ontwikkeling het teologiese denke en beskouings oor die waarheid ingrypend beïnvloed. In Hervormde teologie en baie wyer word aansluiting gevind by 'n relasionele waarheidsbegrip. Van Aarde (1999:19) vra of daar werklik sprake kan wees van 'n konsep soos die waarheid? 'n Positiewe antwoord op hierdie vraag sou impliseer dat waarheid iets objektief vasstelbaar is. Om van die waarheid te praat, sou veronderstel dat 'n subjek onfeilbaar dit uitdruk wat in coreenstemming met objektiewe waarheid sou wees. Biblisiste, skryf Van Aarde, stel die Bybel as sodanig te maklik gelyk met so 'n objektiewe waarheidsbegrip.

Na deeglike studie van Skrifuitsprake oor die waarheid, konkludeer Van Aarde dat hoogstens gepraat kan word van die waarheid wat daar in Jesus is. Hierdie warheid kan beter of slegter in proposisies uitgedruk word, maar kan nooit met 'n proposisie gelykgestel word nie. Omdat daar nie so iets soos die waarheid is nie, of omdat waarheid nie eens-en-vir-altyd in formules vasgeskryf kan word nie, is "die soeke na die waarheid" vir Van Aarde 'n oneindige soeke, 'n reis wat nie eindig nie. Dit beteken nie om jouself aan relatiwisme oor te gee nie, maar 'n welbewuste keuse vir waarheid wat relasioneel is (Van Aarde 1999:20; kyk ook Loader 1987:47-56; 1996:566-589).

Die saak kom ook in 'n sekere sin te berde rondom die vraag na kriteria vir die kerklied, teks en melodie. Bestaan daar objektiewe kriteria vir wat 'n goeie melodie vir die kerklied is? Kloppers (1997:177) beantwoord die vraag negatief. Kerkmusiek het 'n spesifieke funksie. Die waarde van kerkmusiek word bepaal deur die funksie wat dit in die liturgie moet vervul. Sowel die funksie as die kriteria word bepaal deur die teoloe en musici van 'n bepaalde kerk of denominasie. Die siening oor die funksie van musiek in die liturgie word beïnvloed deur die indiwidu of groep se siening oor die Skrif, belydenis, kerk en erediens. Daarom kan die kriteria vir kerkmusiek nooit objektief geldig wees vir 
almal op alle tye en plekke nie. Dit beteken ook vir Kloppers nie relatiwisme in die sin dat elkeen nou kan sing wat hy of sy wil nie.

Ek het self bres instemming met bogenoemde opvattings oor die waarheid en kriteria vir die kerklied, alhoewel ek van mening is dat daar in die teologie te onkrities omgegaan word met die relasionele waarheidsbegrip en die resultate van die postmoderne filosofie en tydgees. Daar word ook nie voldoende ag geslaan op die voorbeelde van relatiwisme wat wel die gevolg is van postmoderne sienings oor waarheid en objektiwiteit nie. Die ontdekking in die postmoderne denke dat waarheid baie groter, anders en meer ongrypbaar is as wat altyd gemeen is, lei baie maklik tot die oortuiging dat daar nie waarheid en waardes meer is nie.

Nogtans, ongeag bree instemming met postmoderne persepsies oor waarheid en die onmoontlikheid van absolute, objektiewe kriteria, wil ek in hierdie studie daaraan vashou dat die onderskeiding tussen die subjektiewe en objektiewe karakter van 'n kerklied, in die sin wat $G$ van der Leeuw (1948) daaraan geheg het, steeds bruikbaar en selfs noodsaaklik is. Daarop word later teruggekom.

\subsection{Sommige psalms, al die psalms, ook gesange?}

Dit is moeilik om goed te begryp waarom kerke op prinsipiële gronde bly staan op 'n standpunt dat slegs die psalmboek, aangevul deur enkele Nuwe-Testamentiese liedere, as kerklied in die Christelike kerk en erediens gebruik mag word. Dat die gevaar van afwyking en dwaalleer kleiner is in gevalle waar 'n mens 'n voorbeeld van 'n Bybelse lied het om te berym, moet toegegee word. Maar dit bied geen waarborg nie. Psalmberymings kan en het ook gedwaal. Psalmberymings kan ook hopeloos en swak wees en baie van hulle is.

Calvyn het voorkeur gegee aan Psalms maar het nie gesange verbied nie. Waarom is dit nie moontlik dat 'n gelowige kunstenaar, gelei deur die Gees van God, 'n bepaalde Bybelse perikoop of selfs net 'n Bybelse tema kan neem en daarvan 'n gedig of lied kan skep wat in alle dele ooreenstem met Bybelse verkondiging en die kerk se belydenis nie?; terwyl daardie persoon in die Bybel in elk geval ook nog voorbeelde het van hoe so 'n lied opgebou behoort te word en na vorm en inhoud daar behoort uit te sien. 
Die wesenlike vraag is nie wat uit die Bybel tot kerklied gemaak is nie, maar of 'n kerklied reg en waar oor God en God se werk sing.

'n Ander vraag is natuurlik of al honderd en vyftig psalms in die psalmbundel geskik is vir gebruik in die erediens. In 'n moderne wêreld en samelewing, gestempel deur verligtheid, verdraagsaamheid en, soos dit tans genoem word, akkommodering, het baie Christene beswaar om byvoorbeeld nog die vloekpsalms te sing. Daarom meen hulle dit behoort weggelaat te word in 'n psalmberyming. So meen teoloe op teologiese gronde dat die gees van die wraakpsalms in botsing is met die gesindheid van liefde en vergewing wat van 'n Christen verwag word. Loader (1979:167) beklemtoon dat die Bybelse psalms reflekteer hoe ou Israel die ingrype van God in hulle lewe ervaar het. Maar die kerklied van vandag moet reflekteer hoe Christene God se ingrype in hulle lewe vandag ervaar. 'n Psalmberyming behoort daarom daarmee rekening te hou dat die psalms gedig en gesing is in die tyd voor Christus se koms terwyl ons lied aangehef word in die tyd ná Christus se koms. As alternatief vir 'n reproduktiewe psalmberyming, stel Loader (1979:173) dat die gedagtepatroon van 'n spesifieke psalm in die lig van wat die perspektiewe wat Christus gebring het, gestel moet word en dat die spesifieke resultaat daarvan dan berym word.

Die psalmkommissie van die Nederduitsch Hervormde Kerk wat in 1983 aan 'n nuwe psalmbundel begin werk het, het op al dié sake ingegaan en het die volgende riglyne neergelê:

- Die wrakpsalms behoort net so deel van ons sangbundel te wees as van ons Bybel. Dit is nie die wraakgedagte wat voorrang geniet nie, maar die Godsgedagte. Die kerk en die gelowiges kan steeds bid dat die vyand se optrede teen hulle beperk moet word.

- Die psalms, soos hulle in die Bybel verskyn, moet berym word. 'n Psalm moet 'n psalm wees. Anders sou daar van gesange gepraat moet word.

- Die corspronklike teks van die psalm moet gebruik word asook die vertalings in Afrikaans van 1933 en daarna. 
- In 'n nuwe beryming moet rekening gehou word met alle tersaaklike nuwe teologiese insigte. Dit moet in nuwe Afrikaans wees maar met die nodige eenvoud. Dit moet voldoen aan die eise van nugterheid.

(Psalmkommissie 1983)

Daarmee is die pleidooi van Loader dus verwerp. Dit wil egter voorkom of die saak nie finaal deurgepraat is nie. In die jongste tyd het Kloppers (1999:292), in aansluiting by uitsprake van Joh Dreyer, J A Loader en 'n besluit van die Nederduitsch Hervormde Kerk se Algemene Kerkvergadering van 1998, sterk betoog dat nie al honderd en vyftig psalms in één vorm in één boek opgeneem moet word nie. Sy beoordeel die huidige standpunt van die Kerk oor die psalmomdigting as verouderd, fundamentalisties en nie in lyn met himnologiese sieninge wêreldwyd nie.

\subsection{Lesse uit die geskiedenis}

Die feit dat naas die psalms ook gesange en ander geestelike liedere vir die erediens geskik geag word, behoort nie die kerk se oë te sluit vir ernstige lesse wat die geskiedenis te leer het nie.

Een daarvan is die voortdurende neiging wat die gesange het om die psalms te verdring. Dit gebeur op die oomblik op 'n ontstellende skaal in die Hervormde Kerk en volgens mededelings van predikante uit die Nederduitse Gereformeerde Kerk ook daar. Geen of hoogstens een psalm word nog in 'n erediens gebruik. Dié verwaarlosing en verdringing is in skril kontras met die ryk gebruik wat die psalm oor eeue in die kerk gehad het (Van Wyk 1994:5).

Uit 'n paar momente en gebeure in die kerkgeskiedenis kry 'n mens die indruk dat daar 'n noue verband bestaan tussen die verwaarlosing van die psalms as kerklied aan die een kant en die vervlakking in die geloof of selfs dwaalleer aan die ander kant. Die ontstaan van bekende dwaalleringe soos onder andere dié van Marcion en die Gnostiek in die algemeen het gedurende die eerste paar eeue van die kerk se geskiedenis hand aan hand geloop met die ontstaan van 'n magdom himnes. Aanhangers van sekere sektes het geweier om psalms te sing. 
$\mathrm{Na}$ die Reformasie gedurende die sestiende eeu besluit die Dordtse Sinode in 1619 dat, naas die psalms van Dawid, daar in die erediens slegs berymings van die tien gebooie, die Onse Vader, die Twaalf Artikels en die lofsange van Maria, Sagaria en Simeon gesing mag word. Die vryheid om nog ander gesange te sing, word aan kerke oorgelaat.

Dié besluit is onder andere beïnvloed deur hewige stryd en verdeeldheid wat gedurende die jare voorafgaande aan die sinode in Dordtrecht ook in die Nederlandse Kerk geheers het, veral rondom die Remonstrante. In 1615 verskyn 'n gesangebundel, saamgestel deur 'n groep Utrechtse predikante. Omdat Remonstrantse invloed Utrecht in dié tyd oorheers het, is dié gesangebundel met sterk agterdog bejeen.

Die gesangestryd wat gedurende die negentiende eeu sou ontstaan as gevolg van die invoering van die uitgebreide gesangebundel in die Nederlandse Hervormde Kerk aan die begin van die eeu, is bekend. In Nederland en in Suid-Afrika was dit onder die oorsake wat tot kerklike afskeidings en skeurings gelei het. En hoe moeilik dié belydenis en erkenning ook al uit die Hervormde gemoed en mond mag kom, bly dit eenvoudig waar: Dit is nie moeilik om aan die hand van die gesange uit dié tyd die ernstige siektetoestand van die kerk en die teologie te diagnoseer nie. Of dit en ander faktore wat daarmee saamhang, hoegenaamd rede vir kerklike skeuring en afskeiding was en is, is heeltemal ' $n$ ander vraag.

Die kerk betaal 'n duur prys vir sy verwaarlosing van die psalms. Die psalms (vgl vir enkele voorbeelde Pss 6; 13; 22; 69; 88) leer die gelowige om die verskriklikste leed en smart van die lewe met God in die gebed uit te worstel en tot gelowige aanvaarding en verwerking daarvan te kom.

Vervreem van die psalms weet die mens nie meer waar en hoe en met wie gepraat moet word oor sonde, nood en frustrasies nie. As beraders nie meer kan help nie, is die einde wanhoop. En gesange wat nog net sing dat twyfel sonde is en geloof berusting, is bankrot. Die mens met die mens se felle lewensproblematiek van vandag het nie sangbundels nodig waarin dinge besing en beskou word nie. In die Bybel is nie besinging nie maar 'n stem, 'n roep uit die diepte. Dié mens word ook min gehelp deur gematigde piêtisties-rasionalistiese liedere vol menslike vroomheid. Daar word ook min waarde geput uit 'n fatalistiese voorsienigheidsgeloof; of vlak rymelary en geredeneer oor 
deug en braafheid; of liedere wat in 'n senukliniek tuishoort; alles karakteristieke wat al aan gesangbundels uit 'n nader en verre verlede toegeken is (Troost 1983:52).

Mag die kerk van 2000 en verder bewaar bly van sulke uitsprake en oordele oor die kerk se lied.

\section{Literatuurverwysings}

Bosch, D J 1991. Transforming mission: Paradigm shifts in the theology of mission. Maryknoll: Orbis Books.

Breytenbach, A P B 1997. Charismatiese tendense in die Nederduitsch Hervormde Kerk van Afrika - 'n terreinverkenning. Kommissie van die Algemene Kerkvergadering, omsendbrief $31 / 97$.

Den Besten, A C 1977. Geding om het lied: Een onderzoek naar de strijd om kerklied en gemeentezang bij Zwingli en zijn geestverwanten, in Honders, A C, Steensma, R \& Wit, J (reds), Het lied en de kerk: Een bundel opstelle, 73-145. Rijksuniversiteit: Groningen.

Den Besten, A C 1981. Het milieu van het liedboek voor de kerken. Rondom het Woord 23(3), 18-22.

Dreyer, T F J 1999. Hervormde etos en die roep om spiritualiteit, in Van Wyk, D J C 20ste eeu Hervormde Teologie, 255-269. Pretoria: Sentik.

Hiltermann, G B J 1970. Inleiding, in Snyder, L L, De Oorlog - de geschiedenis van de jaren 1939-1945. Vierde druk. Zwolle: Koninklijke Uitgeverij.

Honders, A C 1984. Mededelingen: Instituut voor liturgiewetenschap (18). Rijksuniversiteit te Groningen 18, 92-114.

Honders, A C 1988. Liturgie: Barsten en breuken. Kampen: Kok.

Kloppenburg, W 1983. Het portret van grootvader, in Heikens, H (red), Toonsoorten van de Schrift, 107-123. Hilversum: Gooi en Sticht.

Kloppers, E C 1997. Liturgical music: Worship or war? HTS 53, 172-184.

Kloppers, E C 1999. Kerkmusiek: 'n Beskeie bydrae, in Van Wyk, D J C 20ste eeu Hervormde Teologie, 286-299. Pretoria: Sentik.

Loader, J A (red) 1979. ' $n$ Nuwe lied vir die Here. Pretoria-Kaapstad: HAUM.

Loader, J A 1987. Tertium Datur. Oor die etiese waarheidsbegrip. HTS 43, 47-56. 
Loader, J A 1996. 'n Hervormde tradisie as heelmiddel. HTS 52, 566-589.

Oosterhuis, H 1983. Zingen tegen de klippen op, in Heikens, H (red), Toonsoorten van de Schrift, 50-59. Hilversum: Gooi en Sticht.

Psalmkommissie 1983. Notule van 'n vergadering van die Psalmkommissie van die Nederduitsch Hervormde Kerk van Afrika, 28 Junie 1983.

Schulte-Nordholt, J W 1981. Een wijs van Jan Swart bij een lied van Jan Wit? Rondom het Woord 23(3), 36-41.

Sturm, A 1977. Een vergelijkend onderzoek naar Nederlandse reformatorische psalmberijmingen in Honders, A C, Steensma, R \& Wit, J (reds), Het lied en de kerk: Een bundel opstelle, 9-61. Rijksuniversiteit: Groningen.

Troost, A F 1983. Stem en tegenstem: Een onderzoek naar hun verhouding in vier gezangenbundels. Mededelingen no 5, 51-56.

Van Aarde, A G 1999. Wat is waarheid?, in Van Wyk, D J C (red), 20ste eeu Hervormde Teologie, 11-27. Pretoria: Sentik.

Van der Leeuw, G 1948. Beknopte geschiedenis van het kerklied. Groningen: Walters Uitgewersmaatschappij.

Van Uchelen, N A 1971. Psalmen, Deel 1 (1-40). Nijkerk: Callenbach. (Dẹ prediking van het Oude Testament.)

Van Wyk, D J C 1994. Die Psalms in die Nuwe Testament en in die vroee kerk. Die Hervormer 87, Mei 1994, bl 5.

Wilson-Dickson, A 1992. A brief history of Christian music. Oxford: Lion Publishing. 